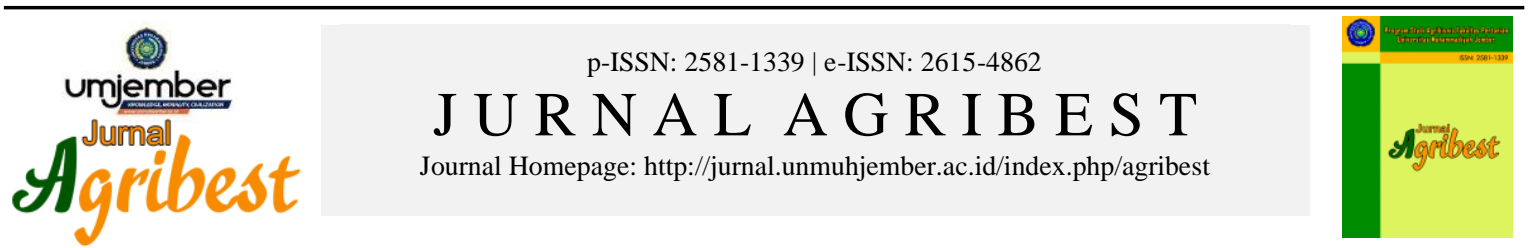

\title{
Analisis Usaha dan Nilai Tambah Ikan Giling pada UD “Annisa 88” di Kota Bengkulu
}

\section{Business Analysis and Added Value of Milled Fish at “UD Annisa 88” in Bengkulu City}

Anggita Dwi Oktavian ${ }^{1}$, Bambang Sumantri ${ }^{1}$, Redy Badrudin ${ }^{1}$, Poppy Antika Sari ${ }^{2}$

${ }^{1}$ Universitas Bengkulu, ${ }^{2}$ Institut Agama Islam Negeri Bengkulu

email: ad.oktaviani@yahoo.com,bsumantri@yahoo.com

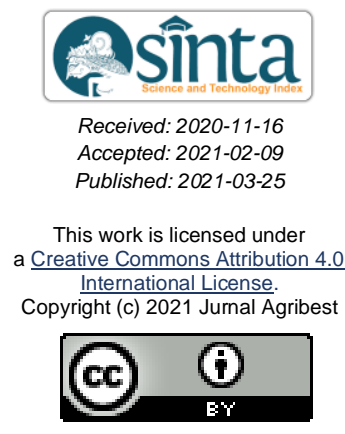

Corresponding Author: Anggita Dwi Oktaviani, Universitas Bengkulu, ad.oktaviani@yahoo.com

\begin{abstract}
Bengkulu City has a fairly long coastline that suitable for industrial development in the fishery sector. Milled fish is one of the product developed by fishery business actors, one of the business actors is UD Annisa 88. Financial planning, recording and calculating during milled fish production is needed to continuity and business development. This research intended to analysis cost of production, break event point, financial performance and added value of milled fish product that manufactured by "UD Annisa 88". The cost of production used variable costing method and than comparised with the calculation by the company.The financial performance analysis used financial ratio method base on balance sheet and profit/lost statement. Added value analysis used Hayami method (Hayami dkk, 1987). The result showed that 1) cost of production method use by the company lack in detailed because some of components are exclude to be calculated; 2) The totak sales in Rupiahs and units are pass over the break event point indicated "UD Annisa 88" succesful to get the profit; 3)Financial analysis show that liquidity, solvability and profitability is in good condition. Otherwise, the activity ratio is not in good condition due the score less than the standard ratio. Based on added value analysis, milled fish product including in the category of high added value.
\end{abstract}

Keywords: added value, BEP, cost of production, financial performance, milled fish

\begin{abstract}
ABSTRAK
Kota Bengkulu dengan garis pantai cukup luas cocok dalam pengembangan industri pada sektor perikanan laut. Ikan giling termasuk produk olahan ikan yang dikembangkan oleh pelaku usaha perikanan, salah satu pelaku usaha tersebut ialah UD Annisa 88. Perencanaan, pencatatan dan perhitungan pembiayaan selama produksi ikan giling sangat diperlukan dalam pengembangan dan kontinuitas usaha. Penelitian ini bertujuan untuk menganalisis harga pokok produksi, break event point, kinerja finansial dan nilai tambah produk ikan giling pada UD Annisa 88. Harga pokok produksi menggunakan metode variabel costing kemudian dibandingkan dengan perhitungan yang digunkanan oleh perusahaan selama ini. Kinerja finansial menggunakan metode perhitungan rasio finansial berdasarkan neraca keuangan dan laporan laba/rugi. Nilai tambah menerapkan metode Hayami (Hayami $d k k$, 1987). Hasil menunjukkan bahwa 1) perhitungan harga pokok produksi yang biasa digunakan oleh perusahaan kurang terperinci karena terdapat beberapa komponen biaya yang tidak masuk dalam perhitungan; 2) total penjualan dalam rupiah maupun per-unit telah melewati batas titik impas yang mengindikasikan UD Annisa 88 berhasil memperoleh laba; 3) analisis kinerja finansial menunjukkan rasio likuiditas, solvabilitas dan profitabilitas berada dalam kondisi yang baik. Akan tetapi rasio aktivitas tidak berada dalam kondisi yang baik dikarenakan nilai yang kurang dari batas minimal; 4) berdasarkan analisis nilai tambah, produk ikan giling termasuk dalam kategori nilai tambah yang tinggi.
\end{abstract}

Kata kunci: BEP, ikan giling, harga pokok produksi, kinerja finansial, nilai tambah, 


\section{PENDAHULUAN}

Industri perikanan tangkap yang ada di Kota Bengkulu rata-rata hanya menjual berupa ikan gelondongan tanpa ada pengolahan lanjutan. Seperti yang diketahui secara umum komoditi ikan memiliki sifat sangat mudah untuk rusak. Untuk mencegah hal tersebut maka ikan segar diolah terlebih dahulu. Salah satu industri yang bergerak di bidang pengolahan ikan ialah UD Annisa 88 dimana usaha tersebut berlokasi di Kampung Melayu Pulau Bai. Jenis olahan ikan laut yang diolah adalah ikan giling. Pihak UD Anissa 88 mendapatkan bahan baku dari kerjasama dengan nelayan sekitar tempat usaha. Karena ikan merupakan komoditi yang cepat rusak maka bahan baku tersebut tidak dapat di stok sehingga tidak dapat dianalisis secara kuantitatif melainkan akan dianalisis secara kualitatif.

Dalam proses pengolahan ikan pasti memiliki biaya yang melekat pada setiap produk ikan giling. Biaya tersebut dapat dihitung dengan menggunakan perhitungan metode harga pokok produksi. Dari harga pokok produksi ini kita dapat menentukan harga jual produk sesuai tingkat keuntungan per produk yang diinginkan. Setiap perusahaan tentu ingin mendapatkan keuntungan. Namun sebelum memproyeksikan keuntungan perusahaan harus mengetahui titik impas dari usaha mereka. Titik impas merupakan titik pengembalian modal yang artinya keuntungan perusahaan sama dengan nol dan tidak mengalami kerugian. Untuk mengetahui titik impas tersebut akan menggunakan perhitungan Break Event Point (BEP).

Tujuan dari pelaksanaan usaha selain mendapatkan keuntungan adalah kontinuitas atau keberlanjutan usaha yang dilakukan. Sehingga dibutuhkan alat analisis yang dapat memberikan gambaran hal tersebut. Salah satunya dapat dinilai melalui kinerja keuangan usaha. Metode yang digunakan adalah analisis rasio keuangan. (Purwaningsih, 2015) dalam penelitiannya menyebutkan kondisi idustri perlu di analisa secara menyeluruh dan diperlukan parameter yang tepat. Nilai tambah produk dapat digunakan untuk melihat sebaran keuntungan stakeholder. Oleh karena itu, untuk mengetahui secara pasti besarnya nilai tambah yang diperoleh akan menggunakan analisis dengan metode yang digunakan oleh Hayami $d k k$ (1987). Berdasarkan uraian di atas maka peneliti tertarik untuk mengetahui: (1) Perhitungan harga pokok produksi (2)Nilai BEP atau titik impas (3) Kinerja Finansial dan (4) Nilai tambah produk ikan giling pada "UD Annisa 88".

\section{METODOLOGI PENELITIAN}

Penentuan lokasi penelitian dilakukan secara sengaja (purposive) yaitu di Kampung Melayu Pulau Baai Kota Bengkulu. Responden yang menjadi target penelitian ini adalah UD Annisa 88 yang bergerak di bidang usaha penggilingan ikan yang cukup besar. Jenis data yang dikumpulkan dalam penelitian ini yaitu data primer dan data sekunder. Data primer diperoleh secara langsung dari responden dengan teknik wawancara kepada pemilik dan karyawan "UD Annisa 88" berdasarkan kuesioner yang telah ditetapkan. Data sekunder diperoleh dari data yang sudah ada sebelumnya. Data ini dari penelitian atau diperoleh dari literatur-literatur dan pustaka yang berhubungan dengan penelitian dan digunakan sebagai pustaka juga perbandingan. Berikut ini adalah metode analisis data yang digunakan.

Analisis Harga Pokok Produksi meggunakan metode variable costing. Menurut Garrison (1994)

metode variable costing dilakukan dengan memperhitungkan semua unsur biaya variabel yang melekat selama proses produksi hingga produk siap dijual.

Analisis BEP adalah suatu teknik analisis untuk mempelajari hubungan antara biaya tetap, biaya variable, keuntungan dan volume kegiatan yang terjadi di suatu perusahaan. (Swastawati, 2011) menyatakan yang dimaksud dengan BEP adalah suatu keadaan dimana total penjualan persis sama dengan total biaya. Perhitungan BEP menggunakan rumus berikut:

$$
B E P(Q)=\frac{\text { Biaya Tetap }}{\text { Margin Kontribusi }}
$$




\section{Break Event Point $(\mathrm{Rp})=\frac{\text { Biaya Tetap }}{\text { Rasio Margin Kontribusi }}$}

Nilai tambah akan dihitung dengan metode yang digunakan oleh Hayami $d k k$ (1987). Analisis kinerja finansial membutuhkan laporan laba rugi dan neraca keuangan. Laporan laba rugi merupakan laporan keuangan yang menggambarkan hasil usaha dalam suatu periode tertentu. Dalam laporan ini tergambar jumlah pendapatan dan sumber pendapatan serta jumlah biaya dan jenis-jenis biaya yang dikeluarkan.Neraca merupakan laporan yang menunjukkan posisi keuangan perusahaan. (Kasmir dan Jakfar, 2003) dalam bukunya menyatakan bahwa posisi keuangan dimaksud adalah posisi aktiva (harta), pasiva (kewajiban dan ekuitas) suatu perusahaan. Perhitungan rasio finansial akan menggunakan tiga rasio, yaitu rasio likuiditas, solvabilitas dan rentabilitas. Rumus yang digunakan untuk setiap rasio akan satu rumus perhitungan saja dengan pertimbangan rumus yang sering digunakan untuk menghitung rasio keuangan. Berikut penjabaran rumus yang akan digunakan :

Rasio Likuiditas

$$
\text { Current ratio }=\frac{\text { Aktiva Lancar }}{\text { Hutang Lancar }} \times 100 \%
$$

Rasio Solvabilitas

Rasio Perputaran Aktiva

$$
\text { Debt to Total Asset }=\frac{\text { Total hutang }}{\text { Total aktiva }} \times 100 \%
$$

$$
\text { Total Asset Turnover }\left(\text { TAT) }=\frac{\text { Penjualan }}{\text { Total aktiva }}\right.
$$

Rasio Rentabilitas/Profitabilitas

$$
\text { Net Profit Margin }=\frac{\text { Laba bersih }}{\text { Penjualan }} \times 100 \%
$$

\section{HASIL DAN PEMBAHASAN}

(Dewi, 2015) dalam bukunya yang berjudul Akuntansi Biaya, Harga Pokok Produksi atau HPP adalah biaya barang yang dibeli dan digunakan untuk diproses sampai selesai, baik sebelum maupun selama periode akuntansi berjalan. Dalam penelitian ini harga pokok produksi dihitung dalam satuan uang bukan satuan jumlah produksi (tabel 1).

Tabel 1. Analisis Harga Pokok Produksi Ikan Giling

\begin{tabular}{clr}
\hline No. & \multicolumn{1}{c}{ Uraian } & Nilai \\
\hline 1 & Jumlah Produk (Kg) & 3.953 \\
& Biaya Bahan Baku & \\
2 & Persediaan Awal & 500.000 \\
3 & Pembelian & 218.438 .600 \\
4 & Ongkos Angkut Pembelian & 0 \\
5 & Total Persedian Akhir & 218.938 .600 \\
6 & Biaya Tenaga Kerja Langusung & 5.533 .500 \\
& BOP Variabel & \\
7 & Listrik & 2.528 .000 \\
8 & Es Balok & 775.000 \\
9 & Kemasan Dalam & 390.000 \\
10 & Kemasan Luar & 3.952 .500 \\
11 & Total BOP Variabel & 7.645 .500 \\
12 & Harga Pokok Produksi & 232.117 .600 \\
13 & Harga Pokok Produksi (Rp/Kg) & 58.727 \\
\hline
\end{tabular}

Sumber : data primer diolah, 2017 
Dapat dilihat pada tabel 1 Harga Pokok Produksi pengolahan ikan giling bernilai Rp 232.117.600 atau sebesar Rp 58.727/Kg dari produk ikan giling yang dihasilkan. Harga pokok produksi juga dapat berfungsi dalam penelusuran jenis biaya yang dikeluarkan. Berdasarkan uraian tersebut dapat diketahui bahwa unsur biaya yang memiliki peran terbesar dalam penyusunan harga pokok produksi adalah bahan baku ikan segar yaitu Rp 218.938.600 dan BOP Variabel sebesar Rp 7.645.500 yang menempati urutan kedua biaya terbesar. (Ramli, 2009) dalam penelitiannya juga menemukan hal yang sama, unsur biaya yang paling besar dikeluarkan adalah bahan baku ikan olahan, yaitu ikan patin sebesar Rp 2.287.500 dan biaya tenaga kerja langsung sebesar Rp 335.000. hal ini menunjukkan bahwa bahan baku adalah komponen terpenting dalam suatu usaha olahan yang berperan besar dalam harga pokok produksi dan penentuan harga jual produk tersebut.

Setelah melakukan perhitungan harga pokok produksi menggunakan metode variable costing maka dapat dibandingkan dengan biaya produksi dengan perhitungan "UD Annisa 88". Perhitungan biaya produksi yang dikeluarkan dapat dilihat pada tabel 1. Perhitungan biaya yang digunakan oleh "UD Annisa 88" termasuk dalam perhitungan harga pokok produksi dengan metode full costing. Metode full costing adalah metode yang menjumlahkan seluruh biaya yang dikeluarkan saat terjadinya proses produksi baik itu BOP variabel maupun BOP tetap. Jika dibandingkan, harga pokok produksi metode variable costing dan metode perhitungan perusahaan menghasilkan nilai yang berbeda. Biaya produksi yang dikeluarkan pada perhitungan perusahaan sebesar Rp 254.396.000 dan perhitungan metode variable costing Rp 232.117.600, ini berarti dengan menggunakan metode variable costing harga pokok produksi yang dikeluarkan lebih sedikit.

Dapat dilihat pada tabel 1 dan tabel 2 biaya plastik atau kemasan yang dikeluarkan antara perhitungan perusahaan dan metode variable costing terdapat perbedaan. Pada perhitungan perusahaan biaya plastik sebesar Rp 650.000 sedangkan pada metode variable costing sebesar Rp. 390.000. Perbedaan tersebut disebabkan karena pada perhitungan perusahaan biaya yang dikeluarkan adalah untuk pembelian plastik dalam jumlah yang melebihi kapasitas produksi ikan giling. Sedangkan pada metode variable costing, biaya plastik yang dikeluarkan telah dikonversikan berdasarkan lembar plastik yang digunakan sesuai dengan jumlah produk ikan giling dan isolasi yang dipakai sebagai perekat.

Jika dianalisis lebih detail, perhitungan perusahaan memiliki beberapa biaya yang tidak termasuk dalam perhitungan biaya produksi ikan giling pada bulan Maret. Rincian biaya yang tidak dimasukkan seperti BOP variabel yaitu biaya kemasan luar. Biaya kemasan luar yang telah ber label atau ber merk "UD Annisa 88" tidak terdapat dalam perhitungan perusahaan karena telah dibeli pada periode produksi sebelumnya. Selain itu, BOP tetap seperti beban listrik, penyusutan peralatan, penyusutan gedung, dan penyusutan handphone juga tidak masuk dalam perhitungan biaya. Padahal setiap penggunaan peralatan dalam proses pengolahan akan memberikan nilai susut selama produksi.

Tabel 2. Biaya Produksi Ikan Giling Perhitungan Perusahaan

\begin{tabular}{clr}
\hline No. & Uraian & \multicolumn{1}{c}{ Nilai } \\
\hline 1 & Jumlah Produk $(\mathrm{Kg})$ & 3.953 \\
2 & Bahan Baku & 218.438 .600 \\
3 & Biaya Tenaga Kerja Tidak Langsung & 4.950 .000 \\
4 & Biaya Tenaga Kerja Langsung & 5.514 .500 \\
5 & Es Balok & 775.000 \\
6 & Plastik & 650.000 \\
7 & Ongkos kirim & 3.340 .000 \\
8 & Operasional & 17.908 .900 \\
9 & Operasional produksi & 63.000 \\
10 & PDAM & 23.000 \\
11 & Listrik & 2.528 .000 \\
12 & Pulsa listrik & 205.000 \\
13 & Total Biaya Produksi & 254.396 .000 \\
14 & Biaya Produksi (Rp/Kg) & 64.355 \\
\hline
\end{tabular}

Sumber : laporan keuangan "UD Annisa 88”, 2017 
Setelah mengetahui harga pokok pokok produksi selanjutnya dapat diketahui harga pokok penjualan. Harga pokok penjualan didapat dari persedian produk yang siap dijual dikurang dengan persediaan akhir yang belum terjual. Jika kedua unsur tersebut telah diketahui maka dapat disusun laporan laba rugi dari pengolahan ikan giling pada bulan Maret 2017. Sehingga akan terlihat pengolahan ikan giling akan mengalami lama atau mengalami rugi.

Dapat dilihat pada tabel 3., laba sebelum pajak diperoleh dari selisih marjin kontribusi dikurang dengan biaya tetap. Laba yang diperoleh "UD Annisa 88" sebesar Rp 18.489.837 pada bulan Maret. Laba yang diperoleh dari pengolahan ikan giling ini termasuk laba yang besar. hal ini menunjukkan ikan segar yang diolah lebih lanjut akan memberikan keuntungan yang lebih. (Situmeang $d k k$, 2017) juga menyebutkan hal serupa dalam penelitiannya, bahwa pengolahan ikan menjadi ikan asin memberikan keuntungan yang cukup besar dimana total penjualan rata-rata per bulan sebesar Rp 70.920.000 dengan keuntungan yang didapat sebesar Rp 9.895.083. Keuntungan tersebut merupakan nilai laba yang didapat sebulum dikurang dengan pajak.

Tabel 3. Analisis Laporan Laba Rugi UD Annisa 88 (Maret 2017)

\begin{tabular}{clr}
\hline No. & \multicolumn{1}{c}{ Uraian } & Nilai (Rp) \\
\hline 1 & Penjualan & 285.120 .000 \\
& Biaya Variabel & \\
2 & Persediaan Awal & 33.754 .929 \\
3 & Harga Pokok Produksi & 232.117 .600 \\
4 & Produk Siap Dijual & 265.872 .530 \\
5 & Persediaan Akhir & 27.291 .212 \\
6 & Harga Pokok Penjualan & 238.581 .318 \\
7 & Biaya Adm \& Penjualan Variabel & 3.490 .000 \\
8 & Total Biaya Variabel & 242.071 .318 \\
9 & Marjin Kontribusi & 43.048 .682 \\
& Biaya Tetap & \\
10 & BOP Tetap & 24.533 .523 \\
11 & Biaya Adm \& Penjualan Tetap & 25.323 \\
12 & Total Biaya Tetap & 24.558 .845 \\
13 & Laba sebelum Pajak & 18.489 .837 \\
\hline
\end{tabular}

Sumber : data primer diolah, 2017

Analisis break event point atau BEP memang dibutuhkan pada setiap usaha baik sekala kecil, menengah maupun skala besar. BEP memiliki manfaat untuk mengetahui volume penjualan minimal dalam produksi agar usaha dapat terus bertahan dan berlanjut. Nilai BEP dapat dilihat pada tabel 4 .

Jika dilihat secara keseluruhan nilai BEP dalam satuan rupiah sebesar Rp 162.658.127, yang mana jika dalam satuan unit berjumlah 2.320 kilogram. Hal ini menunjukkan pihak "UD Annisa 88" minimal harus menjual 2.320 kilogram produk untuk dapat mengembalikan seluruh biaya yang dikeluarkan selama proses produksi pada bulan Maret 2017. Jika "UD Annisa 88" memproduksi kurang dari 2.320 kilogram ikan giling atau pendapatan yang didapat kurang dari Rp 162.658.127 maka usaha ikan giling pada bulan Maret 2017 akan mengalami kerugian.

Nilai BEP yang diperoleh dari "UD Annisa 88" berbeda jika dibandingkan dengan penelitian yang dilakukan oleh Riani, dkk (2013) yang berjudul "Analisis Usaha Pengolahan Ikan Tenggiri (Scomberomorus commerson) Asin Kering di Desa Muara Kintap Kec. Kintab, Kalimantan Selatan. Usaha pengolahan ikan asin yang dilakukan penerimaannya lebih besar dari total biaya dan berada diatas BEP. Sehingga usaha ini masih layak untuk dijalankan baik pada musim maupun saat tidak musim penangkapan. Sedangkan pada "UD Annisa 88" terdapat produk ikan giling yang tidak mencapai BEP. Adanya perbedaan nilai BEP disebabkan karena biaya tetap yang dikeluarkan selama proses produksi lebih rendah dari total penjualan. Jika marjin usaha rendah dapat menyebabkan semakin tingginya biaya tetap yang digunakan. Untuk mencapai BEP atau titik impas membutuhkan nilai penjualan yang lebih besar sehingga total biaya yang 
dikeluarkan tertutupi. Perhitungan BEP juga dapat dilihat berdasarkan grafis, gambar grafis BEP produk ikan giling "UD Annisa 88" dapat dilihat pada gambar 1.

Tabel 4. Break Event Point Produk Ikan Giling"UD Annisa 88"

\begin{tabular}{|c|c|c|}
\hline Nama Produk & BEP per Unit & BEP per Rupiah \\
\hline Tenggiri A & 1.231 & 119.757 .310 \\
\hline Tenggiri $\mathrm{C}$ & 5 & 235.677 \\
\hline Tenggiri Daging Dada & 78 & 3.390 .625 \\
\hline Tenggiri Kulit & 323 & 7.718 .913 \\
\hline Tenggiri Telur & 37 & 1.805 .871 \\
\hline Tenggiri Kepala & 107 & 1.612 .012 \\
\hline Tenggiri Kombinasi & 78 & 6.221 .977 \\
\hline Parang-parang & $(665)$ & $(24.738 .704)$ \\
\hline Pelus & (94) & $(5.151 .765)$ \\
\hline Jabung & 68 & 2.503 .156 \\
\hline Gembolo Karang & (4) & $(188.496)$ \\
\hline Gabus Laut & (0) & $(3.268)$ \\
\hline Total & 2.320 & 162.658 .127 \\
\hline
\end{tabular}

Sumber : data primer yang diolah 2017

Hanya ikan giling tenggiri dan ikan giling jabung yang dapat dihitung dan digambarkan nilai BEP atai titik impasnya. Sedangkan untuk produk ikan giling lainnya seperti parang-parang, pelus, gembolo karang dan gabus, penjualan yang terjadi pada bulan Maret tidak dapat menutupi biaya yang dikeluarkan selama proses produksi. Sehingga untuk ke empat produk tersebut belum bisa dilakukan perhitungan dan dibuatkan grafiknya karena nilai yang dihasilkan masih bias. Selanjutnya untuk total seluruh produk ikan giling "UD Annisa 88", titik impasnya dapat dilihat pada gambar 1 .

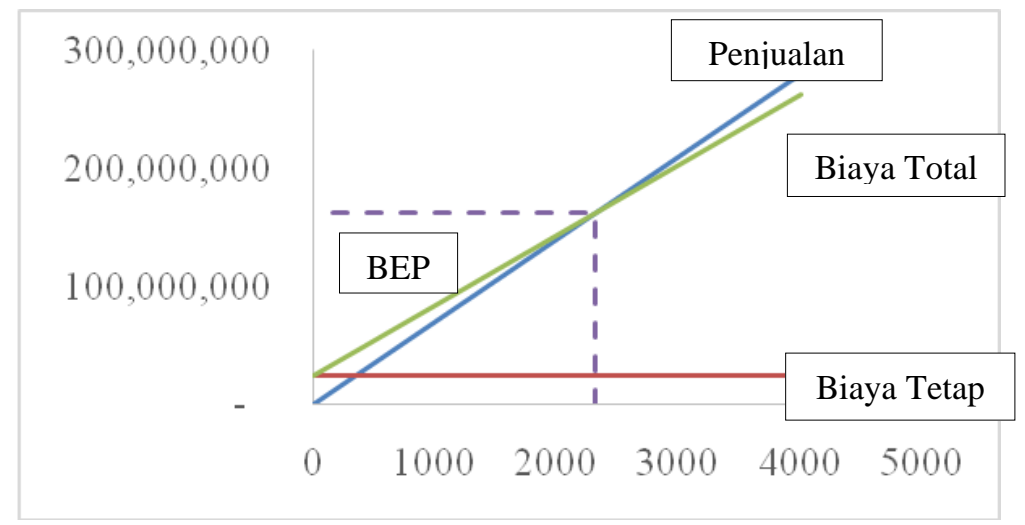

Gambar 1. Grafik BEP Ikan Giling "UD Annisa 88”

Secara keseluruhan, produk ikan giling yang dihasilkan "UD Annisa 88" titik impasnya berada pada 2.320 kilogram ikan giling atau pada Rp 162.658.127 total penjualan. Dapat dilihat pada lampiran 25. Produk ikan giling yang terjual seluruhnya sebanyak 4.066 kilogram dengan total penjualan Rp 285.120.000 pada bulan Maret. Nilai produksi dan penjualan yang berada diatas titik impas menunjukkan bahwa produk yang dihasilkan sudah berhasil mengembalikan seluruh biaya yang dikeluarkan. Sehingga pihak "UD Annisa 88" tidak mengalami kerugian pada bulan Maret atas usaha ikan giling yang dijalankan.

\section{Analisis Kinerja Finansial}

Kinerja finansial dapat bermanfaat dalam menganalisis seluruh kegiatan dalam usaha yang dikerjakan. Baik itu dari segi keuntungan usaha, segi efektifitas pemanfaatan sumberdaya, segi 
efektivitas pemanfaatan modal usaha maupun dari segi pemanfaatan peminjaman modal usaha. Salah satu data yang dibutuhkan untuk dapat menganalisis kinerja finansial adalah sebuah neraca keuangan dari usaha yang dilakukan. Berikut neraca keuangan usaha ikan giling "UD Annisa 88" pada bulan maret 2017:

Tabel 5. Laporan Neraca Keuangan "UD Annisa 88"

\begin{tabular}{lrlr}
\hline Aktiva & & Pasiva & \\
\hline Aktiva Lancar & 50.000 .000 & Utang & \\
Kas & 18.725 .000 & Utang Usaha & 7.000 .000 \\
Piutang Dagang & & & 650.000 \\
Persediaan Ikan Giling & 27.284 .827 & & \\
$\quad$ Produk & 45.000 & & \\
$\quad$ Bahan Baku & 96.054 .827 & Total Utang & 7.650 .000 \\
Total Aktiva Lancar & & Modal & 992.420 .827 \\
Aktiva Tetap & 200.000 .000 & Modal & 992.420 .827 \\
Tanah & 353.220 .000 & Total Modal & \\
Peralatan & $(15.654 .000)$ & & \\
Akm Peny. Peralatan & 123.000 .000 & & \\
Mobil & $(6.150 .000)$ & & \\
Akm Peny. Mobil & 250.000 .000 & & \\
Gedung & $(5.000 .000)$ & & \\
Akm Peny. Gedung & 600.000 & & \\
Merk Dagang & 4.000 .000 & & \\
Inventaris Kantor & 904.016 .000 & & \\
Total Aktiva Tetap & 1.000 .070 .827 & Total Pasiva & \\
\hline Totoal Aktiva & &
\end{tabular}

Sumber : Data primer diolah 2017

Setelah mengetahui neraca keuangan perusahaan, maka kinerja finansial usaha dapat dihitung dengan metode rasio keuangan. Rasio keuangan yang digunakan adalah current ratio (CR), debt to assets ratio (DAR), total asset turnover (TAT)dan net profit margin (NPM). Dari hasil analisis yang telah dilakukan, selanjutnya akan disimpulkan kinerja finansial "UD Annisa 88" secara keseluruhan selama tahun 2017. (Afandi, 2013) menjadi standar rasio acuan yang digunakan dalam penelitian ini. Diketahui dari 4 rasio yang dianalisis 3 diantaranya kinerja finansial dalam kondisi yang baik. Berikut disajikan tabel rasio keuangan untuk mempermudah dalam menganalisis kinerja keuangan.

Tabel 6. Analisis Rasio Keuangan

\begin{tabular}{clccl}
\hline No. & \multicolumn{1}{c}{ Uraian } & Nilai & Standar Rasio & Keterangan \\
\hline 1 & Current ratio (\%) & $1.255,70$ & $>200 \%$ & Sangat Baik \\
2 & Debt to Assets Ratio (\%) & 0,76 & $<100 \%$ & Sangat Baik \\
3 & Total Assets Turnover (Kali) & 0,29 & $>0,5$ Kali & Kurang Baik \\
4 & Net Profit Margin (\%) & 5,83 & $>5 \%$ & Baik \\
\hline
\end{tabular}

Sumber : data primer diolah, 2017

Hal tersebut dapat dilihat dari tingkat likuiditas perusahaan yang berada diatas nilai pedoman rasio. Jika dilihat berdasarkan likuiditasnya melalui perhitungan rasio lancar yang memberikan implikasi kemampuan perusahaan dalam melunasi kewajibannya yang jatuh tempo sangat baik. Sehingga "UD Annisa 88" tidak perlu mengkhawatirkan masalah pengembalian kewajiban lancar karena sudah dijamin dengan aktiva perusahaan yang besar. 
Rasio solvabilitas perusahaan yang dihitung dengan rasio manajemen utang kinerja keuangan UD Annia 88 dalam kondisi yang cukup baik. Hasil ini memberikan implikasi bahwa perusahaan sudah baik dalam mengatur antara utang dan penggunaan modal sendiri. Manajemen aktiva menunjukkan kondisi yang kurang baik. Hasil ini memberikan implikasi bahwa "UD Annisa 88" perlu meningkatkan kemampuan pengolahan aktiva dengan memperbesar tingkat penjualan dan menambah wilayah pemasaran.

Dilihat dari profitabilitas melalui perhitungan rasio NPM kinerja finansial "UD Annisa 88" dalam kondisi yang baik. Hal ini memberikan implikasi bahwa "UD Annisa 88" telah mengolah usaha ikan giling dengan menjamin laba bersih yang cukup baik. Sehingga jika dilihat dari keseluruhan kinerja finansial "UD Annisa 88" pada tahun 2017 berada dalam kondisi yang cukup baik. Namun, nilai tersebut tidak memiliki kriteria secara pasti mengingat belum adanya penelitian mengenai kinerja finansial pada usaha sejenis yaitu ikan giling. Perbandingan hasil penelitian lebih menjurus terhadap jenis usaha dalam cakupan luas.

Kinerja finansial "UD Annisa 88" jika dilihat dari analisis rasio sudah cukup baik. (Lia dkk, 2016) memberikan hasil rasio yang cukup berbeda, pada UKM IRT Ramayana Agro yang bergerak dibidang buah olahan. Disebutkan bahwa rasio likuiditas sangat tinggi dan rasio solvabilitas yang sangat rendah sehingga perusahaan telah menjamin resiko atas usahanya kecil. Sedangkan dilihat dari rasio aktivitas dan rasio profitabilitas kinerja finansial dalam keadaan yang tidak baik karena kinerja perusahaan yang semakin menurun selama dua tahun terakhir akibat menurunnya tingkat penjualan produk buah olahan.

Analisis kinerja finansial akan lebih berguna jika dilihat berdasarkan tren setiap tahunnya. Namun tren kinerja finansial ini tidak dapat dilihat perkembangannya selama beberapa tahun karena "UD Annisa 88" sebelumnya tidak membuat laporan neraca keuangan. Namun laporan neraca keuangan dan analisis berdasarkan rasio keuangan yang telah dilakukan dapat menjadi awal dan pedoman pembuatan laporan untuk tahun berikutnya.

\section{Analisis Nilai Tambah}

Analisis nilai tambah merupakan pertambahan nilai pada suatu produk setelah mengalami proses lebih lanjut. Pertambahan nilai tersebut terjadi karena adanya perubahan bentuk dari ikan segar menjadi ikan giling yang siap digunakan untuk bahan campuran produksi seperti kerupuk ikan, nugget ikan, empek-empek dan bakso ikan.

Tabel 7. Analisis Nilai Tambah Pengolahan Ikan Giling

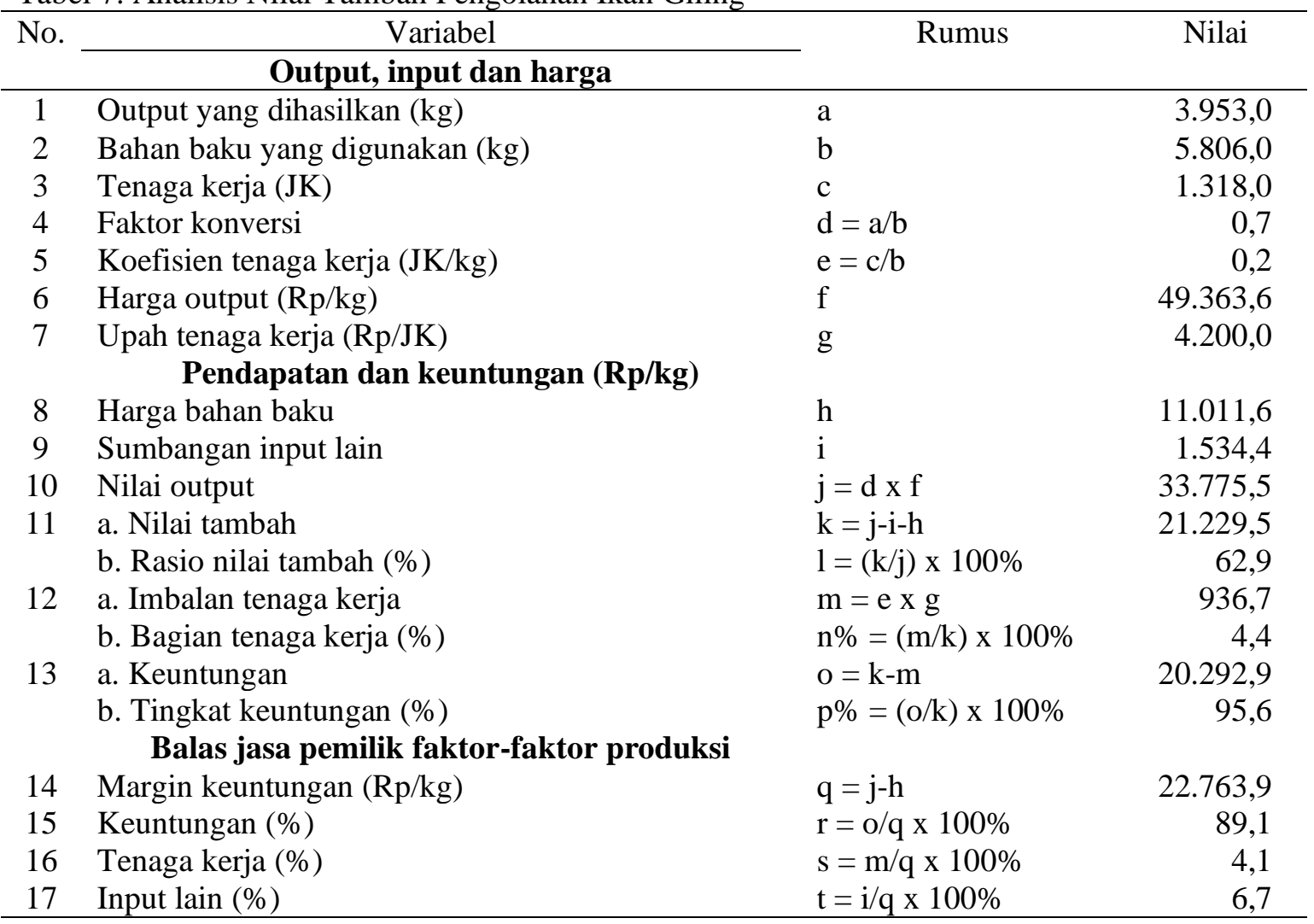

Sumber : data primer diolah, 2017 
Nilai tambah pengolahan ikan giling diperoleh dari pengurangan nilai output per kilogram dengan sumbangan input lain per kilogram dan harga beli bahan baku per kilogram. Rata-rata nilai tambah cukup besar yaitu Rp 21.236,4/Kg dengan rasio 62,9 \% dari usaha pengolahan ikan giling

Perhitungan nilai tambah metode hayami juga memberikan informasi mengenai rasio nilai tambah. (Surya, 2016) menyatakan dalam penelitiannya bahwa rasio nilai tambah dibagi menjadi tiga golongan. Nilai tambah rendah apabila nilai rasio $<15 \%$, nilai tambah sedang apabila nilai rasio berada diantara $15-40 \%$, dan nilai tambah tinggi apabila nilai rasio $>40 \%$. Nilai tambah ratarata yang diberikan selama proses produksi ikan giling memiliki rasio $62,9 \%$, ini berarti tambahan ekonomi juga termasuk tinggi.Nilai tambah ini bertujuan untuk mengetahui tambahan ekonomis yang dihasilkan dari 1 kilogram ikan segar yang diolah menjadi ikan giling. Hal ini dapat berguna sebagai informasi tambahan bagi pengusaha ikan giling dalam peningkatan usahanya.

(Purwaningsih, 2015) yang meneliti tentang olahan ikan lemuru dengan 3 jenis produk menunjukan hasil yang cukup berbeda dari "UD Annisa 88". Dimana ketiga produk ikan lemuru memiliki nilai tambah yang cukup besar. Industry pengalengan ikan memiliki nilai tambah tertinggi yaitu $\mathrm{Rp} 3.500 / \mathrm{Kg}$ dan nilai tambah terendah sebesar Rp 1.800/Kg yaitu produk ikan cold storage. Sedangkan pada "UD Annisa 88" tidak semua produk ikan giling memiliki nilai tambah melainkan terdapat 3 jenis ikan giling yang justru tidak dapat menutup biaya pengolahan yaitu ikan giling parang-parang, pelus dan gembolo karang. Hal iini dikarenakan nilai output dari ketiga jenis ikan tersebut sangatlah kecil.

Pendapatan yang diterima oleh tenaga kerja per jam orang kerja yaitu $\mathrm{Rp} 4.200 / \mathrm{JK}$ diperoleh dari upah riil yang diterima dari keseluruhan proses produksi yang dibagi dengan waktu kerja. Jadi, besarnya pendapatan yang diterima oleh tenaga kerja langsung dari pengolahan 1 kilogram ikan tenggiri segar produk ikan giling adalah $\mathrm{Rp} 1.156 / \mathrm{Kg}$ dan merupakan pendapatan terbesar yang diterima oleh tenaga kerja. Untuk ikan jabung pendapatan yang diterima oleh tenaga kerja hanya sebesar Rp 441/Kg, dimana pada jenis ini merupakan pendapatan yang paling kecil dibandingkan jenis ikan giling dari bahan baku ikan lainnya. Sedangkan imbalan rata-rata untuk tenaga kerja adalah Rp. 936,7/Kg atau sebesar 4,4 \% yang didapat dari bagian nilai tambah ratarata pengolahan ikan giling.

Berbeda dari penelitian yang dilakukan oleh Hamidi (2016), pendapatan untuk tenaga kerja sebesar Rp 1.500 atau 12,37 \% dari nilai tambah yang dihasilkan dari pengolahan ikan giling. Nilai tersebut menunjukkan bahwa pendapatan tenaga kerja yang diterima atas pengolahan abon ikan patin lebih besar dari pendapatan rata-rata yang diterima dari pengolahan ikan giling. Perbedaan ini disebabkan oleh adanya perbedaan tingkat upah yang diberikan dari masing-masing pemilik usaha.

Rata-rata keuntungan yang diterima dari pengolahan ikan giling adalah Rp $20.299,7 / \mathrm{Kg}$ atau sebesar $68,1 \%$ yang diambil dari bagian nilai tambah. (Soeharjo, 1991) dalam hasanah, dkk (2015), berpendapat bahwa jika rasio imbalan tenaga kerja terhadap nilai tambah tinggi, maka agroindustri tersebut lebih berperan dalam meningkatkan pendapatan dan pemerataan lapangan pekerjaan. Jika rasio keuntungan perusahaan terhadap nilai tambah lebih tinggi maka usaha tersebut lebih berperan dalam meningkatkan pertumbuhan ekonomi pada wilayah tersebut. Pengolahan ikan giling "UD Annisa 88" memiliki tingkat keuntungan yaitu 95,6 \%, berarti dalam pengolahan ikan giling lebih berperan dalam meningkatkan pertumbuhan ekonomi.

Dalam rangkaian analisis nilai tambah juga memberikan informasi mengenai marjin keuntungan dari bahan baku ikan segar menjadi ikan giling. Marjin keuntungan ini didistribusikan pada 3 faktor produksi yaitu keuntungan, tenaga kerja dan sumbangan input lain. Rata-rata marjin keuntungan dari pengolahan ikan giling sebesar Rp 22.763,9/Kg. Dari marjin tersebut didistribusikan pada masing-masing faktor antara lain keuntungan $89,2 \%$, pendapatan tenaga kerja $4,1 \%$ dan sumbangan input lain 6,7\% dimana rata-rata distribusi marjin terbesar ada pada keuntungan usaha. 


\section{Simpulan}

\section{SIMPULAN DAN SARAN}

Harga pokok produksi pengolahan ikan giling "UD Annisa 88" dengan metode variable costing lebih kecil dan aliran biaya yang dikeluarkan lebih rinci dibandingkan dengan metode yang digunakan perusahaan. Break event point atau titik impas pengolahan ikan giling "UD Annisa 88" adalah Rp 162.658.127 atau sebesar $2.320 \mathrm{Kg}$ dari semua jenis produk ikan giling. Penjualan sebesar Rp 285.120.000 dengan jumlah produk terjual 4.067 Kg menunjukkan pengolahan ikan giling telah berhasil mendapat titik pulang pokok produksi dan memberikan keuntungan.Analisis kinerja finansial "UD Annisa 88" berada pada kondisi yang baik. Hal ini dibuktikan dengan nilai rasio lancar $1.255,6 \%$, nilai DAR $0,076 \%$, dan NPM 5,84\%. Walaupun perputaran total aktiva termasuk dalam kategori cukup kecil yaitu 0,29\%. Namun secara keselurahan "UD Annisa 88" sudah baik dalam mengatur kinerja finansialnya. Nilai tambah yang diperoleh dari pengolahan ikan giling rata-rata sebesar $\mathrm{Rp} 21.229,5 / \mathrm{Kg}$ dengan rasio 62,9\% sehingga nilai tambah ikan giling termasuk dalam nilai tambah yang tinggi.

\section{Saran}

Dalam hal perincian dan mengklasifikasi biaya, sebaiknya biaya diklasifikasikan sesuai dengan jenis, sifat dan perilakunya agar mempermudah dalam penelusuran,indentifikasi serta memberi informasi lebih akurat. Perhitungan harga pokok produksi perusahaan dengan memasukan segala jenis biaya yang dikeluarkan selama periode produksi belum dapat dikatakan akurat. Perhitungan tersebut masih memiliki kelemahan dalam menghitung harga pokok produksi perusahaan, maka dalam penelitian ini peneliti merekomendasikan perhitungan harga pokok produk dengan menggunakan pendekatan metode selain yang dianut oleh perusahaan, yaitu metode variable costing.

\section{DAFTAR PUSTAKA}

Afandi, D. \& Martoatmojo, S. 2013. Analisis Kinerja Keuangan PT Mayora Indah, TBK di Bursa Efek Indonesia. Sekolah Tinggi Ilmu Ekonomi Indonesia (STIESIA) Surabaya. Jurnal Ilmu dan Riset Manajemen, 2(5), 1-19. https://www.academia.edu/35332018/Analisis_Kinerja_Keuangan_Pt_Mayora_Indah_Tbk _Di_Bursa_Efek_Indonesia_Soebari_Martoatmodjo_Sekolah_Tinggi_Ilmu_Ekonomi_Indo nesia_STIESIA_Surabaya

Dewi, S.P., \& Septian, B.K. 2015. Akuntansi Biaya. Penerbit IN-MEDIA. Bogor.

Garrison, R. H. \& dan Noreen, E. W. 1994. Manajerial Accounting: Concept for planning, control, decision making. Von Hoffmann Press, USA.

Hasanah, U., Mashuri \& Djuwari. 2015. Analisis Nilai Tambah Agroindustri Sale Pisang di Kabupaten Kebumen. Jurnal Ilmu Pertanian, 8(3), 141-149. https://doi.org/10.22146/ipas.10615

Hamidi, W. 2016. Analisis Nilai Tambah Agroindustri Abon Ikan Patin di Desa Koto Mesjid Kecamatan XIII Koto Kampar Kabupaten Kampar Provinsi Riau (Studi Kasus pada CV. Graha Pratama Fish). Jurnal Agribisnis, 18(1): 54-64. http://garuda.ristekbrin.go.id/documents/detail/482437

Hayami, Yujiro, Kawagoe T., Morooka, Y. dan Siregar, M. 1987. Agricultural Marketing and Processing in Upland Java: A Prospective from A Sunda Village. Bogor.Kasmir dan Jakfar. 2003. Studi Kelayak Bisnis. PRENADA MEDIA. Jakarta.

Purwaningsih, R. 2015. Analisis Nilai Tambah Produk Perikanan Lemuru Pelabuhan Muncar Banyuwangi. Jurnal Ilmiah Teknik Industri, 14(1), 13-23. https://doi.org/10.23917/jiti.v14i1.620 
Ramli, M. 2009. Analisis Biaya Produksi dan Titik Impas Pengolahan Ikan Salai Patin (Kasus Usaha Soleha Berseri di Air Tiris Kampar. Jurnal Perikanan dan Kelautan, 14(1), 1-11. http://dx.doi.org/10.31258/jpk.14.01.\%25p

Riani, M.U., Mahreda, E.S. dan Mustika, R. 2013. Analisa Usaha Pengolahan Ikan Tenggiri (Scomberomoruss commerson) Asin Kering di Desa Muara Kintap Kecamatan Kintap Kabupaten Tanah Laut Provinsi Kalimantan Selatan. Jurnal Fish Scientieae 3(5), 41-52. http://ppjp.unlam.ac.id/journal/index.php/FS/article/view/1136

Situmeang, R.G., Hendrik \& Zulkarnain. 2017. Analisis Usaha Pengolahan Ikan Asin di Kelurahan Pondok Batu Kecamatan Sarudik Kota Sibolga Provinsi Sumatera Utara. Jurnal JOM, 4(1): 1-19.

Kasmir \& Jakfar. 2003. Studi Kelayakan Bisnis. Prenada Media. Jakarta.

Swastawati, F. 2011. Studi Kelayakan dan Efisiensi Usaha Pengasapan Ikan Dengan Asap Cair Limbah Pertanian. Jurnal Dinamika Ekonomi Pembangunan 1(1), 18-24. https://ejournal.undip.ac.id/index.php/dinamika_pembangunan/article/view/1654/1429 